Journal of Social Sciences 7 (2): 251-256, 2011

ISSN 1549-3652

(C) 2010 Science Publications

\title{
Challenges Facing the Emerging Economy
}

\author{
${ }^{1}$ Basem Mohammed Lozi and ${ }^{2}$ Dr. Abed Alnaser Al-Ziod \\ ${ }^{1}$ Department of Finance, \\ ${ }^{2}$ Department of Economics, \\ Al-Balqa Applied University, Jordan
}

\begin{abstract}
Problem statement: The purpose of this study was to explore the challenges that Jordanian economy may have to face based on different scenarios in his macro-environment. Specifically, the study focused on the development in the Palestinians and the Iraqi fronts and their impact on the Jordanian economy. Approach: An exploratory research method was utilized. Results: The study findings revealed that the majority of Jordanians believed that the level of conflicts at both fronts are more likely to continue as is "no war-no peace". Jordanians showed a tendency to be more optimistic than pessimistic about the reach for a final settlement for both conflicts. However, Jordanians showed more concern for the situation in Palestine than it is in Iraq. Conclusion/Recommendations: were provided for Jordanian policy makers to deal with economic issues based on each scenario.
\end{abstract}

Key words: Emerging economy, economic reforms, scenarios and future prospects

\section{INTRODUCTION}

Jordan is a constitutional monarchy that gained its independence from Britain in 1946. Jordan is a nonproducing- oil Arab country with relatively few natural resources. But it is a labor-rich exporting state mostly into the Gulf oil-rich Arab states. As of that, Jordan economy has been able to look for remittances of its expatriate workers, foreign loans and economic aid to finance the economical developmental plans.

Over the last decade Jordan adopted several liberalization policies under the auspices of the International Monetary Fund (IMF) and the World Bank (WB).In addition Jordan was acceded to the World Trade Organization (WTO) in 2000, after agreeing to a package of trade and investment liberalization measures as well as improvement in protections for foreign-intellectual property. A privatization program which was launched in 1995 has been undertaken to reduce Jordanian government involvement in the economical activities. The program aims at enhancing private sector role through the sale of shares to technically advanced strategic investors, expanding the financial market through public share offerings and reducing subsidies and consolidating public finance.

Since 1999 under the ruling of His Majesty King Abdullah II Jordan has been practicing a major political, economical and regulatory reforms. For instance, Jordan joined the world Trade Organization, signed free trade agreement with the United State in
2000 and signed an association agreement with the European Union in 2001. Despite these major reforms Jordan economy has to deal with high rate of unemployment and heavy public debt that coupled with the unexpected increase of the energy cost (Burnside and Dollar, 2000; Daskupta et al., 2002; Hoekman and Djankov, 1997; Shaban et al., 2001; Rivlin, 2001).

Ironically, despite the instability in the MiddleEast, the relative stability of business environment and his reform policies make Jordan a safe haven for Arab and foreign investments. The Jordanian economy achieved an economic growth rate of $7.5 \%$ in the year 2004 that was the highest level since 1995 . While the population growth for the same year was only $2.5 \%$. This statistically means an increase per capita income for Jordanian. Fortunately, this trend in Jordanian economy continued over the years 2004-2007. During this period, real GDP growth rate average reached 5.4\% while population growth rate average was $2.9 \%$ implying average per capita income growth of by $2.6 \%$. Although unemployment rate remains within two digits (15\%), by the end of 2006. inflation was moderate and estimated to be at $3.5 \%$. The study aims to shed the light on the significant economic trends and an overlook for its future. Information about the MiddleEaster states business environments may reveal insights into Jordanian economic dynamics and potential challenges and opportunities that policy makers, managers, business people and researchers have to tackle (Karakaplan, 2005; Maghyereh and Sweidan, 2004; Ruhashyankiko, 2005; Saif and Debartolo, 2007). 
Purpose of the study: The primary purpose of this study is to explore the prospects of Jordanian economy in the next five years. Specifically, the study lays emphasis on challenging issues that Jordan might have to counter to maintain its economic growth rate. The study also examines the impact of the reform policies on the economy and the scenarios that the economy may faces in the future based on the current situation.

\section{MATERIALS AND METHODS}

An exploratory research method was used. Data were acquired from 200 MBA students from the Jordanian universities. The character of the sample indicates that $100 \%$ of the students are familiar with economic and managerial terms and the situation in the Middle-East. Of the respondents $65 \%$ were male students and 35\% were female students.

The participants were asked to respond for series of questions related to the three scenarios.

First optimistic scenario: This scenario related to the perception of the situation in Iraq will stabilize and solved and Jordan economy will be booming.

Second pessimistic scenario: The situation in Iraq and Arab-Israeli conflict will be getting worst and will have a negative impact on Jordan economy.

The third scenario: The situation in Iraq and the ArabIsraeli conflict are more likely to stay as is and the Jordanian economy will adopt the situation.

An analysis of Jordanian economy has been made with secondary data. Data have been collected from government publications. Central Bank of Jordan publications (CBJ) like annual reports and monthly statistical bulletin, Department Of Satiations publications (DOS) like annual statistics.

Jordanian economy and economic reforms: At the time of its independence the Jordanian economic policies seemed going in the right direction. The government embarked on a development plan to build the country infrastructure. Unfortunately, the country early plans were hit hard by the 1948 Arab-Israeli war and its aftermath of millions of Palestinian refugees and the need to administer the West Bank. Jordan planning efforts started again at the early 1960s. But the instability and uncertainty in the Middle-East left its marks on the planning efforts for the last part of the past century. However, Jordan developmental plans was able to build a reliable infrastructure for the health, education and financial industries achieving a GDP growth rate of $3 \%$ and population growth of $2 \%$. The economic policies moved toward more liberalization in the 80 's to achieve growth rate of over $5 \%$. A major economic reform was undertaken by the 1990s leading for a growth rate of $6 \%$ to reach over $7 \%$ in the fiscal year 2003-2004 (Abed, 2003; Brautigan and Knack, 2004; Chan, 2004; Mongardini and Tahsin, 2003; Maghyereh, 2003).

The New Economic Policy (NEP-1990) introduced major changes in the areas of trade policies, monetary and financial policies, fiscal and budgetary policies and institutional reforms. The salient features of NEP-1990 are: (1) Liberalization (internal and external), (2) Drastic reforms in trade, monetary, financial and fiscal policies, (3) Redirecting scarce public sector resources to areas where the private sector is unlikely to enter, (4) Globalization of economy. In 1989 the Jordan Dinar (JD) collapsed due to high government expenditure on infrastructure as well as the accumulation of significant foreign debt. The IMF interceded in 1989 for the first time to help reduce foreign debt and improve balance of payment in the country. The JD was tied to the dollar and after several years confidence in the currency was reinstituted. Jordan was a star pupil in taking the IMF "Pill" of liberalization, including the reduction of government's excessive spending and the reduction of customs and quotas. But the first Gulf war in 1990 shocked the country with an influx of refugees from the Gulf countries which became an economic burden.

Therefore, major financial and fiscal policies were taken to remedy the new situation such as the introduction of $7 \%$ sales tax including energy and food items. In order to sustain the loss of government revenue from its reduced tariffs due to an open trade policy. Another shock for the economic reform was the conflict between Israelis and Palestinians in 1999. As a result of these independents, stabilization and socioeconomics restructuring for Jordan economy was not truly "trickled down". Unemployment and poverty levels are still high in the country. Currently, the performance of Jordan' economy is mixed. JDP is rising noticeably, exports are increasing, foreign reserves are at a record high and currency is extremely stable due to constricted central bank policies.

Another reform is the combination of dynamic and deep structural legislature and regulating reforms aimed at paving the way for a free economy with free trade, privatization and the development of sophisticated capital market. Jordan's attempts are to create comparative advantage for itself and exploit its location in the region as well. Jordan's deregulation, privatization and introduction of new property rights reforms have also helped to create over 10000 jobs in the IT industry over the past 3 years. While Jordan also suffers from a balance of payment situation and foreign debt, it is hoped to overcome this issues in the near future. As a region, the Middle East only absorbs $0.5 \%$ 


\section{J. Social Sci., 7 (2): 251-256, 2011}

of the world's Foreign Direct Investment (FDI), with two-third of the amount going to Saudi Arabia and Egypt. Levels in Jordan, a small country of only 5.7 million people with minimal natural resources, remain low, but have grown tremendously since the early/mid 1990’s.

Future FDI prospects looks promising given the ongoing economic reforms and opportunity for regional peace. Strides made through almost all sectors of Jordan's economy make it an appealing option for foreign business investment. This research will discuss the factors which have provided a road-map is foreign investment opportunity. Understandably, firms, especially those in an industry as complex as financial services, must consider a variety of factors when assessing investment options. This research will also analyze the current climate in Jordan and opportunities and obstacles going forward.

Jordan's current market conditions: As mentioned before, Jordan took several steps toward moving its economy from mixed economy to free market economy. National industries, in Jordan are in the process of privatization (e.g., Telecommunications, Potash, electricity), an important step developing nations must take to increase efficiency of institutions for their citizens and make the economy more appealing for long-term investors. Formerly rigid laws governing foreign company investment levels, ownership and operation within the Kingdom are being rewritten to the benefit of foreign investors. More study must be done and help is needed at the local level. For instance became one of only four countries that signed a Free Trade Agreement (FTA) with the United States in December 2004. As a result, Jordan exports to the US totaled JD. 905 million in 2006 that accounted for almost $31 \%$ of the national exports.

The reform policies promote foreign investment. There is no formal screening process, but foreign investors face minimum capital requirements. Residents and non-residents may hold foreign exchange accounts. There are no restrictions or controls on payments, transactions, transfers, or repatriation of profits. Real estate purchases require approval. Foreign investment may not exceed $50 \%$ in construction, wholesale and retail trade, transport, wastewater treatment, food services, travel agent services, import and export services and advertising. However, foreigners are prohibited from investing in investigative and security services, sports clubs, store quarrying, custom clearance services and land transportation.

Jordan has reaped undeniable benefits through their use of Qualified Industrial Zones (QIZ) and free zones, which have provided needed stimulus to investment and export levels. For example, the goods produced in the QIZ can be exported, duty-free, to the US. In the free zones, goods may pass through, exempt from customs duties or import taxes and industrial facilities may be leased from the government at reduced rates. Asian investors, less skittish about the regional tensions, have been quick to take advantage of these zones.

Jordan has a moderately well developed financial services sector. There are more than 30 banks operating in the country with working capital around $\$ 20$ billion. Overall, the banks can be characterized as well established, conservative and profitable. However, banks responding by reducing interest rates paid on deposits and interest rates charged on loans, albeit at a slower than cuts on Central Bank of Jordan (CBJ) base rates. In addition, the CBJ adopted a series of measures geared towards developing the activities of licensed banks, strengthening their soundness and improving their competitiveness.

Five year outlook: The challenge for the Jordanian policy makers and economists is to maintain the economic growth rate in the long run. Jordanian policy makers are aware with the changing nature of political, economical and social environment in the Middle East. This research will discuss three likely scenarios based on current situation.

The first scenario:

- Gulf War II ends, peace/stability reigns in Iraq. Resources are tapped, regional trade begins

- Israeli/Palestinian conflict subsidies, negotiations ensure. Tensions ease

- Jordanian government can focus on reforms and gathering investment

- A FDI flow to newly stabilized region in the nearterm-Jordan is an immediate beneficiary

A highly unlikely, but positive outcome of the recent turmoil is described above. Undoubtedly, this would lead to tremendous opportunity both in the country and in the region. Over a five-year period, assuming stability on all fronts, investment in the region would sky-rocket and Jordan would be an immediate beneficiary in the light of their location and the reformed economy. GDP grow the rates of 5-8\%, may be reached and needed attention would be paid to ongoing reforms. Perhaps most importantly, this scenario would allow the government to focus solely on the nation's economic infrastructure without having to constantly address security and political concerns, while also counting potential investors. Given that a 
prime deterrent to investment in Jordan, along with geopolitical instability, are the "micro" issues in firm's operational set-up, this attention is crucial. Continued emergence of the Amman Stock Exchange (ASE), as well as, consolidation and continued profitability in the banking sector are very likely in this case.

Competition will increase as new participants enter, driving efficiency and encouraging borrowing by domestic business as well as the emerging middle-class. Some domestic banks are likely victims, but the gains for the citizens seen in improved burrowing rates and expanded bank services.

The second scenario:

- The conflict in Iraq will stay the same as it is now (no war/no peace). Iraq in chaos, civil strife, radicalism and resented US presence

- The Palestinian- Israeli conflict will stay as is

- Government focused solely on maintaining security of nation, not investment and reforms

This is the worst case scenario and would lead down a very difficult road. Once again, they would be victimized by their sensitive location and uncontrollable factors. Growth levels plummet in the region and especially in Jordan, now surrounded by conflict on all sides. Government would be primarily focused on maintaining rule in this situation. Economic reforms are either cast aside or abandoned altogether.

Quite simply, companies not in the market will stay away and companies with a presence in Jordan may leave. This will have a dramatic effect on FDI, both long and short term and be potentially devastating to the economy given the effort that they have made to make themselves appealing. The ASE would rapidly lose steam as the recent growth of foreign participation in the market dries up. The banks would likely survive, given their strong position serving the existing citizens and business. Unfortunately, this may also mean even less efficiency and local business and citizens paying the price. An important consideration is that planned unification of markets between Arab countries would undoubtedly be put on hold, to the determinant of each of them. The CBI would need to institute very strict measures to control inflation and interest rate in the face of what would likely be economic crisis.

The third Scenario:

- Gulf war II ends more towards Iraqi stability/implementation of effective governance

- Enmity between Israel/Palestine continues, dividing the Middle East and discouraging firms
- Government continuous to balance economic reform efforts with more pressing social concerns

- Many western firms remain hesitant to enter, await resolution and view larger-term options

This is the most realistic of all scenarios.

Importantly, it predicts a slower, but consistent, rebuilding of Iraq on both economic and political levels with continued regional tension. An expected short term dip in the GDP (Due to lost FDI and DDI) will undoubtedly occur. GDP growth will turn into 5-6\% growth by 2008 and continuous onwards given the reconstruction of Iraq and renewed hope for the region. The government can devote time to both the economy and political considerations. Businesses grow and the middle class continue to emerge. Some firms moving into the region take advantage of Jordan's location and investment incentive programs. However, other firms remain on the sidelines due to tensions in the West Bank and Gaza strip. The continuation of conflict between the Palestinians and the Israelis considered a more polarizing issue to the citizens of Jordan and other Arab countries and a prime deterrent to potential investors.

Based on careful analysis, these are the trends expected in the next few years. Continued development of the stock exchange seems very likely. This will lead to increased trade volume, transparency and capital liquidity.

In a country like Jordan which is on Middle East, unfortunately economics and politics go side by side on the same tract and even at same pace. Reforms in Jordan involve many programs and plans; however, the previous governments tested this bitter experience in their tenure in the last ten years. To illustrate an example, the government had to face a stiff opposition from the various sectors in the society about decision related to introduction of new taxes in the country. Other key issues like cut in subsidies, the government had no other option but to roll back its decision. The strategic decisions related to disinvestments were halted due no various political and judicial reasons. It is high time now that the government should line up to its expectations of fulfilling the promises which it has made in the past. Irrespective of which government is coming, it should focus on carrying the reform process ahead, especially by passing the critical economic legislations during tenure of the parliament; there are lots of promises to be fulfilled by the governments. For instance the promise to bring changes in labor laws, the policy issues related to small scale industries and infrastructure financing, these are important issues which needs decision action. If Jordan can over come or address these challenges, then after the next five years Jordan can have a great and bright future. 


\section{J. Social Sci., 7 (2): 251-256, 2011}

\section{DISCUSSION}

The research findings: 175 students responded for the survey. Of them 105 were male students and 70 were female students.

As shown from Table 1 about one-third of the respondent students seemed to be optimistic about the situation in Iraq. Of them (29\%) was males and 36\% was female students.

However, Table 1 also indicated that $55 \%$ of the respondents feels that no change in the situation in Iraq. There were no significant differences between male (55\%) and female (56\%). Both seemed neither optimistic nor pessimistic.

While, $14 \%$ of the total respondents (16\% males and $08 \%$ females) indicated that the situation in Iraq is going to be worst.

Table 2 revealed that only 13\% of the respondents were optimistic about the ending of the Arab-Israeli conflict. Of them (09\%) was males and 18\% was female students.

Unfortunately, the majority of respondents $77 \%$ indicated the level of conflict between the Arab and Israeli are more likely to stay the same. Although there was no significant differences between the respondent according to gender, more male students (80\%) showed that will be no changes more than their counterparts the female students (74\%), Surprisingly, only $26 \%$ (11\% males and $8 \%$ females) of the respondents demonstrated that they are pessimistic and level of conflict between Arab and Israeli will be worst than the current situation.

The research findings revealed that Jordanians are neither optimistic nor optimistic about situation in Iraq and the Arab-Israeli conflict. It sounds that there is a silent wishing for a solution for those conflicts because of their proximity of Jordan and their importance for its economy. Iraq is in the Eastern border, while Palestine is Jordan western neighbor.

Jordanian sees Iraq is a major market for Jordanian product and services. Furthermore, Iraq is oil- rich Arab states and geographically located at Eastern border of Jordan. Historically, Iraq is an important source of energy for Jordan. As mentioned earlier, Jordan has been the safe haven for continuous waves of Palestinians refugees before and since 1948. Almost a large number of Jordan populations are originally Palestinians or Palestinians refugees. Additionally, Jordanian economy has a strong tie with the West Bank economy also the end of this conflict will give Jordan another access to the Mediterranean Sea, such an access will contribute for reducing cost for Jordanian import and Export.
Table 1: Number and percentage of respondents regarding the Iraqi Scenario

\begin{tabular}{llll}
\hline Gender & $\begin{array}{l}\text { 1st scenario } \\
\text { optimistic }\end{array}$ & $\begin{array}{l}\text { 2nd scenario } \\
\text { more likely }\end{array}$ & $\begin{array}{l}\text { 3rd scenario } \\
\text { pessimistic }\end{array}$ \\
\hline Male & $30(29 \%)$ & $58(55 \%)$ & $17(16 \%)$ \\
Female & $25(36 \%)$ & $39(56 \%)$ & $06(08 \%)$ \\
Total & $55(31 \%)$ & $97(55 \%)$ & $25(14 \%)$ \\
\hline
\end{tabular}

Table 2: Number and percentage of respondents for each scenario

\begin{tabular}{llll}
\hline Gender & $\begin{array}{l}\text { 1st scenario } \\
\text { optimistic }\end{array}$ & $\begin{array}{l}\text { 2nd scenario } \\
\text { more likely }\end{array}$ & $\begin{array}{l}\text { 3rd scenario } \\
\text { pessimistic }\end{array}$ \\
\hline Male & $10(09 \%)$ & $83(80 \%)$ & $12(11 \%)$ \\
Female & $13(18 \%)$ & $52(74 \%)$ & $05(8 \%)$ \\
Total & $23(13 \%)$ & $135(77 \%)$ & $26(10 \%)$ \\
\hline
\end{tabular}

\section{CONCLUSION}

The study showed that in the Middle-Eastern countries, including Jordan, economics and politics go hand in hand on the same tract and even at same pace. Because of the changing nature of alliances and partnership among the Middle-Eastern states, economic policies and plans have to be flexible to be adjusted and some times to make a turn over or even may to search for alliances outside the region. This situation is complicated by the fact, that all Middle-Eastern economies are in the same transitional stages and may producing same or similar products and in an attempt to satisfy their people to avoid being interlocked to others in the region.

Jordan, as located in the crossroad between the Middle-Eastern countries has been facing a sensitive situation to maintain a balancer role in the region. For instance, Jordan tried to play a neutral positive role in all the Middle-East conflicts. Ironically, Jordan's economy has been highly integrated to the economies of his neighbors. Therefore, this research findings support the current Jordanian attempts to convert into a free market economy since free market economy is a condition for democracy. Furthermore, this research supports Jordan integration policies into the global market by joining the WTO and other free trade agreements with United States and the European Union. The research study also strongly recommends that Jordan policy makers continue their efforts toward stabilizing the region because of its importance for Jordan development and progress. Additionally, Jordan policy makers are recommended to diversify the economy to be an industrialized instead of being a service based economy. Furthermore, Jordan policy makers has to be pragmatic and study toward lowering level of expectations among Jordanian to avoid social pressures on the decision makers to trade off short term stability for long term developments. 
In sum, Jordan could be the newly economic tiger in the Middle-east as those small economies and countries in the Fare east. Jordan could achieve such position by capitalizing and balancing the three issues: educated populations, strategic location and conscious political and economical reforms under a sold banner of security, security and security.

\section{REFERENCES}

Abed, G.T., 2003. Unfulfilled promise: Why the middle east and north Africa region has lagged in growth and globalization. Fin. Dev., 40: 1-11.

Brautigan, D.A. and S. Knack, 2004. Foreign aid, institutions, and governance in Sub-Saharan Africa. Econ. Dev. Cult. Changes, 52: 255-285.

Burnside, C. and D. Dollar, 2000. Aid, policies, and growth. Am. Econ. Rev., 90: 847-868.

Chan, K., 2004. Risk Instability and the Pattern of Foreign Direct Investment in the Middle East and North Africa. IMF Working Study No. 139, pp: 15. http://ideas.repec.org/p/imf/imfwpa/04-139.html

Daskupta, D., J. Keller and T.G. Srinivasan, 2002. Reform and Elusive Growth in the Middle EastWhat Happened in the 1990s? .World Bank Working Study No. 25. http://siteresources.worldbank.org/INTMENA/Res ources/WP25.pdf

Hoekman, B. and S. Djankov, 1997. Effective Protection and investment incentives in Egypt and Jordan during the transition to free trade with Europe. World Dev., 25: 281-291. DOI: 10.1016/S0305-750X(96)00097-6
Karakaplan, M., 2005. Aid and Foreign Direct Investment: International Evidence. Turkish Economic Associat. http://ideas.repec.org/p/bil/bilpap/0505.html

Maghyereh, A. and U. Sweidan, 2004. Government Expenditures and Revenues in Jordan, What Cause What? Multivariate Cointegration Analysis. The Hashemite University, Department of Finance, Jordan. DOI: 10.2139/ssrn.523882

Maghyereh, A., 2003. Financial liberalization and stability demand for money in emerging economies: Evidence from Jordan. Applied Economet. Int. Dev., http://ideas.repec.org/a/eaa/aeinde/v3y2003i3_10.h tml

Mongardini, J. and S. Tahsin, 2003. Estimating Indexes of Coincident and Leading Indicators: An application to Jordan. IMF Working Paper. http://ideas.repec.org/p/imf/imfwpa/03-170.html

Rivlin, P., 2001. Economic Policy and Performance in the Arab World. 1st Edn., Lynne Rienner Publishers, London, ISBN-10: 1555879322 pp: 237.

Ruhashyankiko, J., 2005. Why Do Some Countries Manage to Extract Growth from Foreign Aid. IMF Working

Paper. http://ideas.repec.org/p/imf/imfwpa/05-53.html

Saif, I. and D. Debartolo, 2007. The Iraq War's Impact on Growth and Inflation in Jordan. University of Jordan, Centre for Strategic Studies. http://www.jcss.org/uploadeconomic/118.pdf

Shaban, R.A., D. Abu-Ghaida and A.S. Al-Naimat, 2001. Poverty Alleviation in Jordan: Lessons for the Future. 1st Edn., World Bank, Middle East North Africa Reigion, Washington, ISBN-10: 0821349589, pp: 70. 